\title{
Analysis of Sub-sectors of Processing Industry in Banggai Re- gency Indonesia using Local Superior Products
}

\author{
Nurhidayah Layoo ${ }^{1}$, Wahyudin Rahman ${ }^{2}$, Sutrisno K. Djawa ${ }^{3}$, \\ Jurtan Latuba ${ }^{4}$, Nurmawati Mambuhu ${ }^{5}$, Irwan Moridu ${ }^{6}$, Rini Hadiyati ${ }^{7}$, \\ Nurcahya H Possumah ${ }^{8}$, Risno Mina ${ }^{9}$, Nuning Kurniasih ${ }^{10}$ \\ 1,2,3,4,5,6,7, Management Study Program, Economy and Business of Faculty, Muhammadiyah Luwuk University, Luwuk, Indonesia \\ ${ }^{9}$ Law Study Program, Law of Faculty, Muhammadiyah Luwuk University, Luwuk, Indonesia \\ ${ }^{10}$ Faculty of Communication Sciences, Library and Information Science Program, Universitas Padjadjaranty, Bandung, Indonesia \\ *Corresponding author E-mail: wahyu@unismuhluwuk.ac.id
}

\begin{abstract}
The purpose of this research was to determine superior local products in the sub-sector of the processing industry of Banggai Regency Indonesia by using Analytic Hierarchy Process (AHP) approach.. The research was conducted based on several criteria such as the production facility, market potential, human resource support, uniqueness, and economic contribution. The data were taken by purposive sampling method by considering the capacity and ability of respondents to provide the necessary data, here the respondents consisted of 15 SMEs stakeholders, and the expert stakeholders of 4 heads of division in Industry and Trade Department, 4 heads of division in Cooperative and SMEs, 7 academics in Faculty of Industry Technic, and 5 in Faculty of Economics. The data were collected through Focus Group Discussion (FGD), questioner, and in-depth interview. The result shows that the superior local products of Banggai Regency in the processing industry sub-sector are processed food and beverage products, with an emphasis on SME empowerment located in aspects of human resources, production facilities and utilization of market potential.
\end{abstract}

\section{Keywords: Local Superior Product, Processing Industry, Analytic Hierarchy Process}

\section{Introduction}

In Indonesia, the existence of small and medium enterprises (SMEs) in which there is a household-scale processing industry, cannot be separated from national economic growth because the existence of SMEs is a form of the economic life of most Indonesian people, therefore in an effort to build a national economy, sub the SME sector gets priority to be fostered and developed. in order to be more efficient and able to develop independently. The development of SMEs is important given the role of SMEs in the recovery of the national economy in the crisis era, both in terms of the number of businesses, the aspect of job creation, and in terms of national economic growth as measured by Gross Domestic Product (GDP)

In the Banggai Regency GDP 2017 posture, the processing industry gives the first largest contribution, replacing the category of agriculture and fisheries which have always been dominant in the regional economic structure. This change in economic structure provides a positive indication of the economic development of Banggai Regency. According to the Central Bureau of Statistics of Banggai Regency [1] [2] [3], the trend of the role of the processing industry continues to increase from $10.78 \%$ in 2014 to $26.12 \%$ in 2016 with a growth rate of $80.77 \%$. The per capita income of the population increased. This high income per capita as an effect of increasing. per capita income of residents who work in the processing industry.

The various types of existing processing industries, the food and beverage processing industry show a dominant contribution, with the number of business units reaching $45.3 \%$, absorbing $46.5 \%$ of the workforce, and production volume reaching $33.1 \%$. Then the furniture industry is in the second position with a number of business units of $23.9 \%$, absorbing $24.6 \%$ of the workforce and production volume reaching $18.9 \%$ [2].

Referring to the magnitude of the contribution to GDP, the number of business units of production volume and labor, processed food and beverage products seem feasible to be developed into superior regional products from the processing industry subsector. Susanto [4] criteria for superior regional products are the absorption of labor and its role in the economy. Kusdiana and Gunardi [5] that economic contribution is one of the criteria of LSP, but not only that, it must also have market potential and uniqueness. Likewise Porter in Magretta [6] stated that one of the bases of competitive advantage is differentiation. The Minister of Home Affairs Regulation Number 9 of 2014 [7]sets the criteria for regional superior products, namely products, both in the form of goods and services, which are produced by cooperatives, small and medium scale businesses that have the potential to be developed by utilizing all the resources owned by the region, both natural resources, human resources and local culture, as well as bringing income to the community and the government which is expected to be an economic force for the region and the local community as a potential product that has competitiveness, selling power, and the driving force towards and able to enter the global market.

GDP criteria, production data, stakeholder opinion, and sociocultural consideration are often taken into consideration in determining the priority scale of Local Superior Products development. However, then it is replaced with the Analytic Hierarchy Process (AHP) due to the complex process of selecting the superior products. The complexity of LSP decision-making problem lies not 
only in the uncertainty or imperfection of the information, but also in the complex issues, in which many factors are involved. Saaty [8], the developer of a decision analysis method called AHP, explained that a complex problem could be described into groups and then is organized into a hierarchical structure, so that the problem will be more well-organized and structured. Optimization of LSP aims to increase employment opportunities, regional economic growth, Own-Source Revenue, as well as regional per capita income, and ultimately cut the poverty [9]. To achieve so, the findings from the research are required to determine the LSP of Banggai Regency, set the priority scale from sub-sector of the proceesing industry.

\section{Method}

The population were all the stakeholders related to the LSP development in Banggai Regency Indonesia. The research used purposive sampling by selecting 15 SMEs subjects. The expert group consisted of 3 heads of division in Industry and Trade Department, 3 heads of division in Cooperatives and SMEs, and 3 heads of division in Food Crops Horticulture and Plantation Department, 7 academics from the Faculty of Economics, and 5 academics from Faculty of Agriculture.

The secondary data included legislation, research results, GRDP data, population data, data on agricultural production, retrieved from Central Bureau of Statistics and other related institutions. The primary data was collected from the research sample. The researchers carried out the data collection by conducting in-depth interview to small business owners and FGD on the expert group. The data analysis methods used were AHP method was used to set the priority scale of Banggai Regency LSP from agriculture sectors, using five criteria as follows: raw material availability, market potential, Human Resource (HR) support, uniqueness, and economic contribution. It was supported by Expert Choice software.

\section{Result and Discussion}

SMEs in the processing sub-sector have various types of products that can be selected as the local superior product alternatives they show active community involvement, high market demand and data production. Therefore, the products of the sub-sector in Banggai Regency are classified under two categories: processed food and beverage products, and furniture products.

The government must improve the quality of human resources because the data show that the average of community education level 7.73 years, meaning that they only attend the elementary school and do not complete their secondary school. According to stakeholders, human resources are the most priority because they will affect business performance. This is consistent with the study of Layoo and Rahman [10] [11] which found that the entrepreneurial orientation of business actors has a positive and significant effect on the performance of Micro Small Enterprises. This shows that to improve company performance, SMEs in Banggai Regency must be able to maintain and improve their entrepreneurial orientation which includes innovative, proactive, courageous risks, autonomy and competitive aggressiveness.

To improve the quality of human resources, the government should collaborate with private sector and universities, as issued by to Presidential Instruction Number 6 of 2007 [12] that aims to take necessary measures through Business Development Service Provider (BDS-P) and the empowerment of SMEs.Procurement of production facilities, one of the most important steps is to improve both the quantity and quality of the processed food and beverage products by procuring machinery and other necessary equipment. In addition, it is necessary to develop supply chain management to ensure the availability of raw materials so that the production is on time with the right place and amount.
Table 1: Processing Industry according to Total Company, Investment Value, Human Resource, and Production Value, 2016

\begin{tabular}{|c|l|l|l|l|l|}
\hline No & Industry & $\begin{array}{c}\text { Total } \\
\text { Company } \\
\text { (unit) }\end{array}$ & $\begin{array}{c}\text { Investment } \\
\text { Value (000) }\end{array}$ & $\begin{array}{c}\text { Human } \\
\text { Resource } \\
\text { (org) }\end{array}$ & $\begin{array}{c}\text { Production } \\
\text { Value (000) }\end{array}$ \\
\hline 1 & $\begin{array}{l}\text { Food } \\
\text { industry }\end{array}$ & 148 & $13,963,029$ & 1,113 & $8,366,184$ \\
\hline 2 & $\begin{array}{l}\text { Furniture } \\
\text { industry }\end{array}$ & 187 & $18,643,779$ & 736 & $8,211,679$ \\
\hline 3 & $\begin{array}{l}\text { Beverage } \\
\text { industry }\end{array}$ & 103 & $5,310,780$ & 278 & $6,001,401$ \\
\hline
\end{tabular}

Source: BPS Banggai Regency, [1]

The representation of the hierarchy is as follows:

Objective : Determine the LSP of Banggai Regency in the processing industry

Criteria : The availability of production facility, market potential, human resource support, uniqueness, and economic contribution

Alternative : There are two superior products (see figure1).

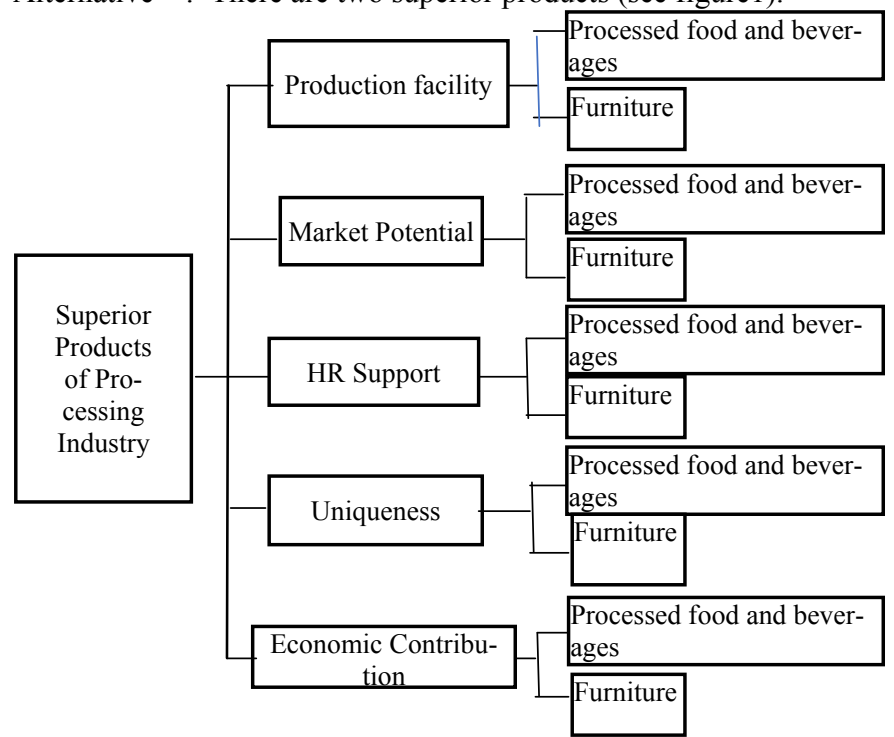

Fig.1: Criteria and Alternative of Superior Products of Processing Industry SMEs

Optimize the potential of the market; the government should be more concerned with the local consumer market. BPS [2] data shows that food and beverage expenditure of Banggai Regency is IDR $58,360 /$ capita/month or $15.44 \%$ of total consumption expenditure. It ranks just second after the rice expenditure. Due to the increase of population, domestic and international visitors of the area, local consumer market will develop larger. The strategic position of Banggai Regency as a transit area of eastern Sulawesiincreases the domestic and international visitors continue to visit. From the data of Luwuk immigration office, as reported by the BPS data of Banggai Regency, the number of foreign visitors continue to increase in 2016 by more than 400 people.In addition, people are also interested in Banggai Regency due to the oil and gas investment.

\begin{tabular}{lc|}
\hline Priorities with respect to: & \\
Objective: SUPERIOR PRODUCTS OF & \\
BANGGAIREGENCY & .307 \\
HUMAN RESOURCES & .300 \\
PRODUCTION FACILITIES & .248 \\
MARKET POTENTIAL & .105 \\
ECONOMIC CONTRIBUTION & .041 \\
UNIQUENESS & \\
\hline Inconsistency $=0.06$ with O missing judgments \\
\hline
\end{tabular}

Fig.2: Criteria Weight Sequence 
The processed food products also need to be considered as a great potential for export. According to the export report by Ministry of Industry of the Republic of Indonesia in January and February 2017 (http://www.kemenperin.go.id/kinerja-industri), it shows that that food industry sector becomes the largest foreign exchange contributor of Indonesian processing industry exports in 2017. In January 2011, it was recorded that the industry made US \$ $2,843.06$ million and US $\$ 2,622.87$ million in the following month [13]. The surplus of processed food export has been reportedly continuing to increase compared with other industries, so it becomes the largest contributor. The largest export destination of Indonesia for processed food products in China, the United States and India.

To utilize the overseas market opportunities, the local government alongside with Chamber of Commerce and Industry (Kadin) and Indonesian Young Entrepreneurs Association (HIPMI) of Banggai Regency need to conduct surveys to find the types and specifications of processed food and beverages that area most liked by the export destination countries of Indonesia. In addition, it is necessary to continue improving the quality of SMEs human resources in parallel with the provision of production facilities and SMEs capital access.

\section{Priorities with respect to: \\ Goal: Superior Productsof Banggai Regency in Pro- cesing Industry \\ Processed Food and Beverage product \\ Furniture products \\ Inconsistency $=0.00$ with 0 missing judgments}

Fig. 3: LSPof processing industry based on the availability of Production Facilities Criteria

\section{Priorities with respect to: \\ Goal: Superior Productsof Banggai Regency in Pro- cesing Industry \\ Processed Food and Beverage product \\ Furniture products \\ Inconsistency $=0.00$ with 0 missing judgments}

Fig. 4: LSP of processing industry Based on Potential Market Criteria

\section{Priorities with respect to: \\ Goal: Superior Productsof Banggai Regency in Pro- cesing Industry \\ Processed Food and Beverage product \\ Furniture products \\ Inconsistency $=0.00$ with 0 missing judgments}

Fig. 5: LSP of processing industry Based on HR Support Criteria

\section{Priorities with respect to: \\ Goal: Superior Productsof Banggai Regency in Pro- cesing Industry \\ Processed Food and Beverage product \\ Furniture products \\ (n)onsistency

Inconsistency $=0.00$ with 0 missing judgments

Fig. 6: LSP of processing industry Based on Uniqueness Criteria

\section{Priorities with respect to: \\ Goal: Superior Productsof Banggai Regency in Pro- cesing Industry}

Processed Food and Beverage product

Furniture products

Inconsistency $=0.00$ with 0 missing judgments

Fig. 7: LSP of processing industry Based on Economic Contribution Criteria

Processed food and beverages are produced by local SMEs spread all over sub-districts using raw materials acquired from agriculture and fishery sector managed by the local community. The products range from various types of chips, floss, sambal, cake, juice, syrup, and herbal drinks. The availability of production facilities, food and beverage products are more prioritized than furniture products. This is due to the fact that the processed food and beverage products are produced by SMEs using local raw materials from agriculture and fisheries and the level of product availability is relatively high. It is in contrast to furniture products where the raw materials are limited.

Figure 4 shows that food and beverage products rank first in the priority list, meaning that the respondents see a greater potential for processed food and beverage market. Furthermore, BPS data shows that the percentage of population expenditure per capita of Banggai Regency for food and beverage product expenditure is $15.44 \%$ of the total monthly consumption expenditure or ranks second after the grain expenditure.

Based on the criteria of human resource, uniqueness and economic contribution, processed food and beverage products top the priority list. It is supported by Banggai Regency BPS data in 2017 that show the food and beverages industry employed 1,391 people, while the furniture industry employed 736 people. The total number of food and beverage companies are 251 SMEs. This contributes to the increase of community income and government revenues through tax and retribution, which will increase the overall regional economy in the end.In sum, the processing industry of food and beverage plays a significant role in reducing the unemployment rate of an area, increasing income, and reducing the poverty rate. This role will be greater in the future along with the seriousness of government and community in developing this subsector.

\section{Conclusion}

Many processing products are included in the top priority of LSP of Banggai Regency. Because all of them are important, it is necessary to improve the quality of SMEs in order to increase the local economic growth and expand to the market overseas. The processing industry consists of food and beverage products as well 
as furniture products. The government should actively encourage the SMEs to prioritize the LSP of the processed food and beverages. In addition, the SMEs empowerment lies in the aspects of human resource, production facilities and utilization of market potential

\section{Acknowledgment}

This paper is part of the results of the study entitled Determining Local Superior Products Using Analytic Hierarchy Process Approach: A case study in Banggai Regency Indonesia. That the superior products of Banggai Regency are coconut products, Pelagic fish, processed food and beverage products.

\section{References}

[1] BPS Kabupaten Banggai, "BPS KabupatenProduk Domestik Regional Bruto Kabupaten Banggai Menurut Lapangan Usaha 20122016," BPS Kabupaten Banggai, Banggai, 2017.

[2] BPS Kabupaten Banggai, "Banggai dalam angka," BPS Kabupaten Banggai, Banggai, 2017.

[3] BPS Kabupaten Banggai, "Indikator ekonomi Kabupaten Banggai," BPS Kabupaten Banggai, Banggai, 2017.

[4] T. A. Susanto, "Identifikasi potensi ekonomi masyarakat Kabupaten Tapin," 2009. [Online]. Available: Susanto, Adi Try 2009. Identifikhttps://www.academia.edu/6639622/Identifikasi_Produk_Komodi tas Unggulan.

[5] Kusdiana and Gunardi, "Pengembangan produk unggulan UMKM Kabupaten Sukabumi," Trikonomika Vol 13 No , pp. 153-171, 2014.

[6] J. Magretta, Understanding Michael Porter, Panduan paling Penting tentang Kompetisi dan Strategi, Yogyakarta: Andi, 2012.

[7] Menteri Dalam Negeri RI, "Peraturan Menteri Dalam Negeri nomor 9 tahun 2014 tentang pedoman pengembangan produk unggulan daerah," Depdagri RI, Jakarta, 2014.

[8] T. Saaty, "Decision Making with The Analytic Hier-archy Process," Int. J. Services Sciences, Vol. 1, No. 1, 2008.

[9] Chuzaimah and Mabruroh, "Chuzaimah dan Mabruroh, 2008. Identifikasi Produk Unggulan Berbasis Ekonomi Lokal untuk Meningkatkan PAD di Era Otonomi Daerah," in Seminar Nasional Aplikasi Sains dan Teknologi 2008, IST AKPRIND, 2008.

[10] N. Layoo and W. Rahman, " Hubungan Orientasi Kewirausahaan dengan Kinerja Usaha Mikro Kecil di Kabupaten Banggai," in Prosiding Konferensi Nasional Ekonomi, Manajemen dan Akuntansi, Jakarta, 2018.

[11] N. Kurniasih, P. M. Yusup and E. Kuswarno, "Empowerment of women to support family economy in Sukamukti Ciamis Indonesia," in 1st International Conference Postgraduate School Universitas Airlangga: Implementation of Climate Change Agreement to Meet Sustainable Development Goals (ICPSUAS 2017), Surabaya, 2018.

[12] Presiden RI, "Instruksi Presiden nomor 6 tahun 2007 tentang percepatan sektor riil dan pembangunan usaha mikro kecil dan menengah," Sekretariat Negara, Jakarta, 2007.

[13] Kementerian Perindustrian Republik Indonesia, "Laporan ekspor impor hasil pengolahan Januari dan Februari 201," Kemenperin RI, Jakarta, 2017. 